\title{
Effects of Blood Transfusion on the Risk of Hepatitis C Infection in Hemodialysis Patients: A Meta-Analysis
}

\author{
Yuli Astuti1), Yulia Lanti Retno Dewi²), Bhisma Murti1) \\ ${ }^{1)}$ Masters Program in Public Health, Universitas Sebelas Maret \\ ${ }^{2)}$ Faculty of Medicine, Universitas Sebelas Maret
}

\section{ABSTRACT}

Background: It is estimated that $2 \%$ of the world's population (about 123 million people) was infected with hepatitis C. Blood transfusion is one of the therapies, but this therapy is at risk of being a transmission medium for hepatitis B infection. Hemodialysis patients are in the group at risk of having hepatitis $\mathrm{C}$ infection. Patients with a history of blood transfusions in this group increase the incidence of hepatitis $\mathrm{C}$ infection. This study aimed to determine the estimated effect of blood transfusions on hepatitis $\mathrm{C}$ infection in hemodialysis patients with a metaanalysis.

Subjects and Method: Meta-analysis was conducted by searching for articles from databases such as Google Scholar, PubMed, Springer Link, and Research Gate. The keywords were "blood transfusion" OR "risk factor" AND "hepatitis C infection" OR "TTI" OR "HBV" AND "patient hemodialysis" OR "Patient renal failure". The inclusion criteria were full-text articles, from 2000-2020, with a cross-sectional study design. The articles were analyzed using RevMan 5.3.

Results: There were 9 articles analyzed. The results showed that blood transfusions increased the incidence of hepatitis $\mathrm{C}$ infection in hemodialysis patients $(\mathrm{aOR}=1.55 ; 95 \% \mathrm{CI}=1.19$ to 2.03 ; $\mathrm{p}=0.001)$ and $\mathrm{I}^{2}=90 \%$. Based on the meta-analysis result, there was no publication bias.

Conclusion: Blood transfusion affects hemodialysis patients with hepatitis $\mathrm{C}$ infection.

Keywords: blood transfusion, hepatitis Cinfection, hemodialysis patients

\section{Correspondence:}

Yuli Astuti. Masters Program in Public Health, Universitas Sebelas Maret. Jl. Ir. Sutami 36A, Surakarta 57126, Central Java. Email: yuliastuti1224@gmail.com. Mobile: 083821875621

Cite this as:

Astuti Y, Dewi YLR, Murti B (2020). Effects of Blood Transfusion on the Risk of Hepatitis C Infection in Hemodialysis Patients: A Meta-Analysis. J Epidemiol Public Health. 05(03): 339-347. https://doi.org/10.26911/jepublichealth.2020.05.03.08.

cc) (i) Journal of Epidemiology and Public Health is licensed under a Creative Commons Attribution-Non Commercial-Share Alike 4.0 International License.

\section{BACKGROUND}

Hepatitis is an inflammation of the liver. Generally, hepatitis is usually caused by viruses. It is also caused by other infections, alcohol, drugs, or other risky behavior. Hepatitis can be cured but it can turn into fibrosis, cirrhosis, and liver cancer (WHO, 2020).

There are five types or categories of hepatitis, namely hepatitis A, B, C, D and E. These five types of hepatitis are the biggest concern because it causes potential death, potential spread, and outbreak. Specifically, type $\mathrm{B}$ and $\mathrm{C}$ cause chronic disease in hundreds of millions of people. Besides, these types are the main causes of cirrhosis and liver cancer (WHO, 2020).

Hepatitis $\mathrm{C}$ is caused by the hepatitis $\mathrm{C}$ virus infection. Hepatitis $\mathrm{C}$ is a type of hepatitis causing liver damage such as cirrhosis and liver cancer. It was estimated that $2 \%$ of the world's population (around 123 million people) is infected with hepatitis $\mathrm{C}$. In several cases, the patients do not have signs and symptoms, so that the patients do not realize that he has been infected with the hepatitis $\mathrm{C}$ virus (Oliviera et al., 2010). 
Hepatitis Cvirus (hepatitis C) infection leads to an acute stage without symptoms. Therefore, some of the sufferers did not know that they had hepatitis C. However, about $75 \%$ of acute sufferers would have a high risk of chronic hepatitis $\mathrm{C}$ infection. In 2 decades, hepatitis $\mathrm{C}$ infection increased: $27 \%$ caused cirrhosis of the liver and $25 \%$ caused hepatocellular carcinoma (HCC). It was estimated that 71 million people worldwide had chronic hepatitis C (Han et al., 2019). Based on the result of the study, the level of exposure to Hepatitis B and hepatitis $\mathrm{C}$ was high due to blood transfusion. The risk of transmission through blood transfusions was 500,000 out of 2,000,000 people who carried out blood transfusions (Engle et al., 2014).

Blood transfusion is one of the interventions to save lives. It does not mean that it is not a risk-free intervention. It can transmit infectious diseases through blood transfusions such as hepatitis B, hepatitis C, syphilis, and HIV/AIDS. Many cases of hepatitis B infection and hepatitis $\mathrm{C}$ infection occurred in the adult population that was associated with the use of blood transfusion. It occurred because hepatitis $\mathrm{B}$ and hepatitis $\mathrm{C}$ are infective through blood and body fluids, thus including in vertical transmission (La Torre and Saulle, 2016).

Hemodialysis patients are one of the groups of people that were at risk of having hepatitis $\mathrm{C}$ infection easily. Immunosuppression in hemodialysis patients is considered a factor causing hepatitis $\mathrm{C}$ infection (Contantio et al., 2018).

In 2002, the number of hepatitis C infections in hemodialysis patients in America was 5 times higher than in other patients. However, the incidence of hepatitis $\mathrm{C}$ infection in hemodialysis patients in Europe was higher than in patients. The number was varied (UK 2\%, Sweden 8.8\%, Spain 25\%, Italy 27\%, and Turkey 30\%) (Caragea et al., 2018).

\section{SUBJECTS AND METHOD}

\section{Study Design}

This study used meta-analysis and systematic review. The articles that were used metaanalysis were available on the electronics databases at PubMed, Google Scholar, Research Gate, Scopus, Springer Link, and Science Direct.

\section{Study Variables}

The inclusion criteria were full-text articles in English. This study used a cross-sectional study with multivariate analysis by providing the results of the Adjusted Odds Ratio (aOR). The articles were conducted in 2000-2020.

The exclusion criteria were non-full-text articles, articles that used RCT studies, quasiexperimental design, and study protocols, articles not in English. The articles used bivariate analysis, thus presenting ORs only, different means, and similar articles.

\section{Operational Definition of Variables} Blood transfusion was one of the health services. It was a therapy by utilizing human blood which was processed into a blood component. The blood transfusion given must match the blood type between the blood donor and the recipient (Yelima et al., 2019). Hepatitis $\mathbf{C}$ was an infection caused by the hepatitis $\mathrm{C}$ virus. Hepatitis $\mathrm{C}$ virus infection (hepatitis C) was a single-stranded, small, and closed RNA virus. This virus had a diameter of $56-65 \mathrm{~mm}$. The core of this hepatitis $\mathrm{C}$ virus was $45 \mathrm{~mm}$ (Morozov and Lagaye. 2018).

Hemodialysis was a process of removing blood from the human body to be replaced by components or blood products from outside (Vadakedath and Kandi. 2017).

\section{Data Analysis}

This study used RevMan 5.3 to analyze the data. This study used a random effect analysis. 


\section{RESULTS}

The articles were searched using journal databases, including PubMed, Springer Link, Research Gate, Elsevier, Science Direct and Google Scholar. The keywords were "blood transfusion" OR "risk factor" AND "hepatitis
B" AND "hepatitis C" OR "TTI" AND "Among patient hemodialysis" OR "Patient renal failure" AND "cross-sectional". The article review process could be seen in the search flow as follows:

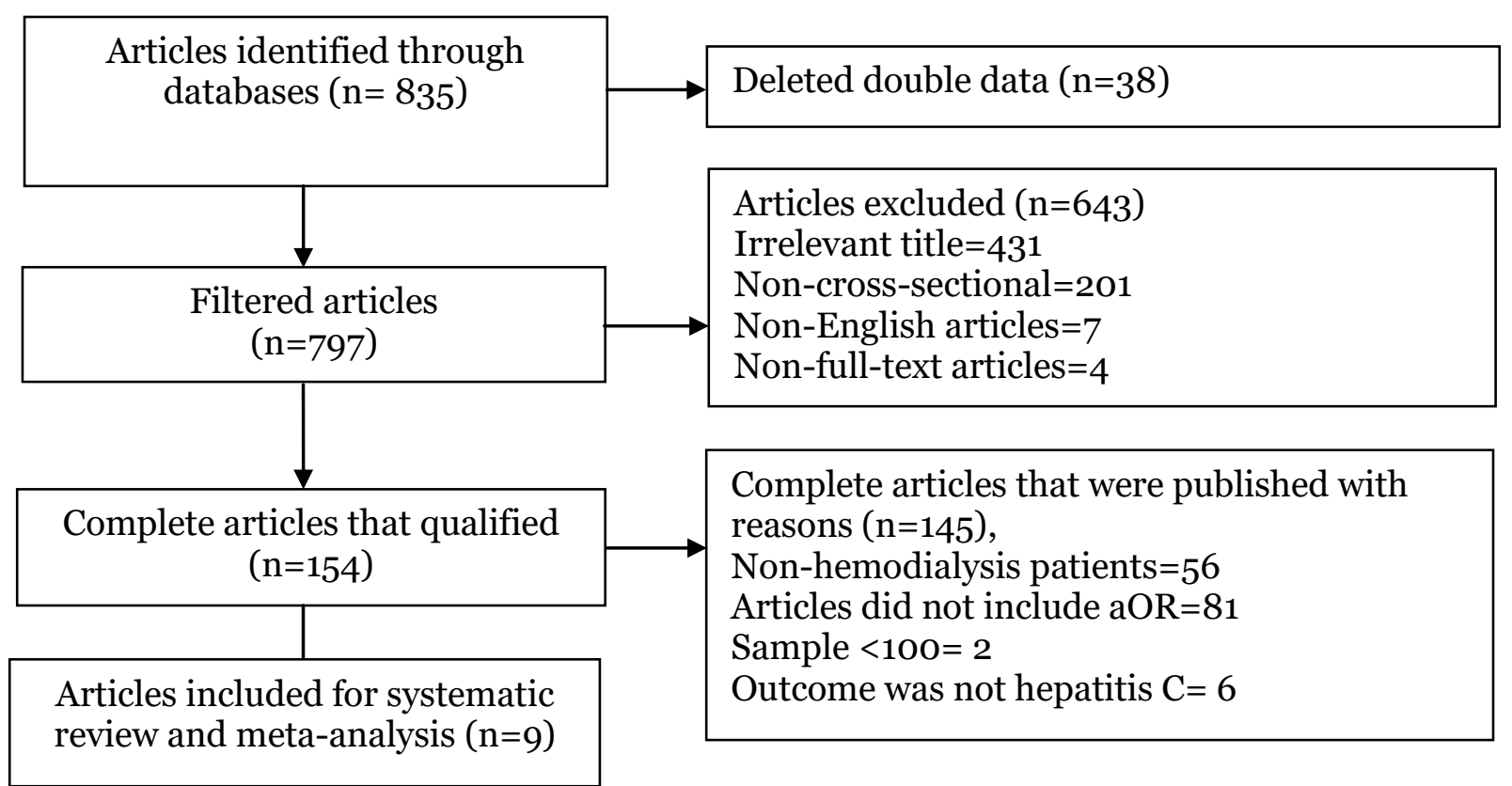

\section{Figure 1. PRISMA flow diagram}

There were 835 articles in the first search. After eliminating published articles, there were 797 articles. 154 articles qualified for further full-text review. Full-text articles were excluded due to the following causes:

1. Did not use observational studies

2. Did not use a cross-sectional design

3 . The population was not hemodialysis patients

4. Did not include the aOR value from the results of the multivariate analysis
5. The population was under 100

Based on a study related to the effect of blood transfusion on hepatitis infection in hemodialysis patients, there were 9 articles with the distribution of regions; 5 articles on the Asian Continent, 2 regions on the African continent, and 2 regions on the South American Continent. The figure of the article findings analyzed based on the primary study is presented in Figure 2: 


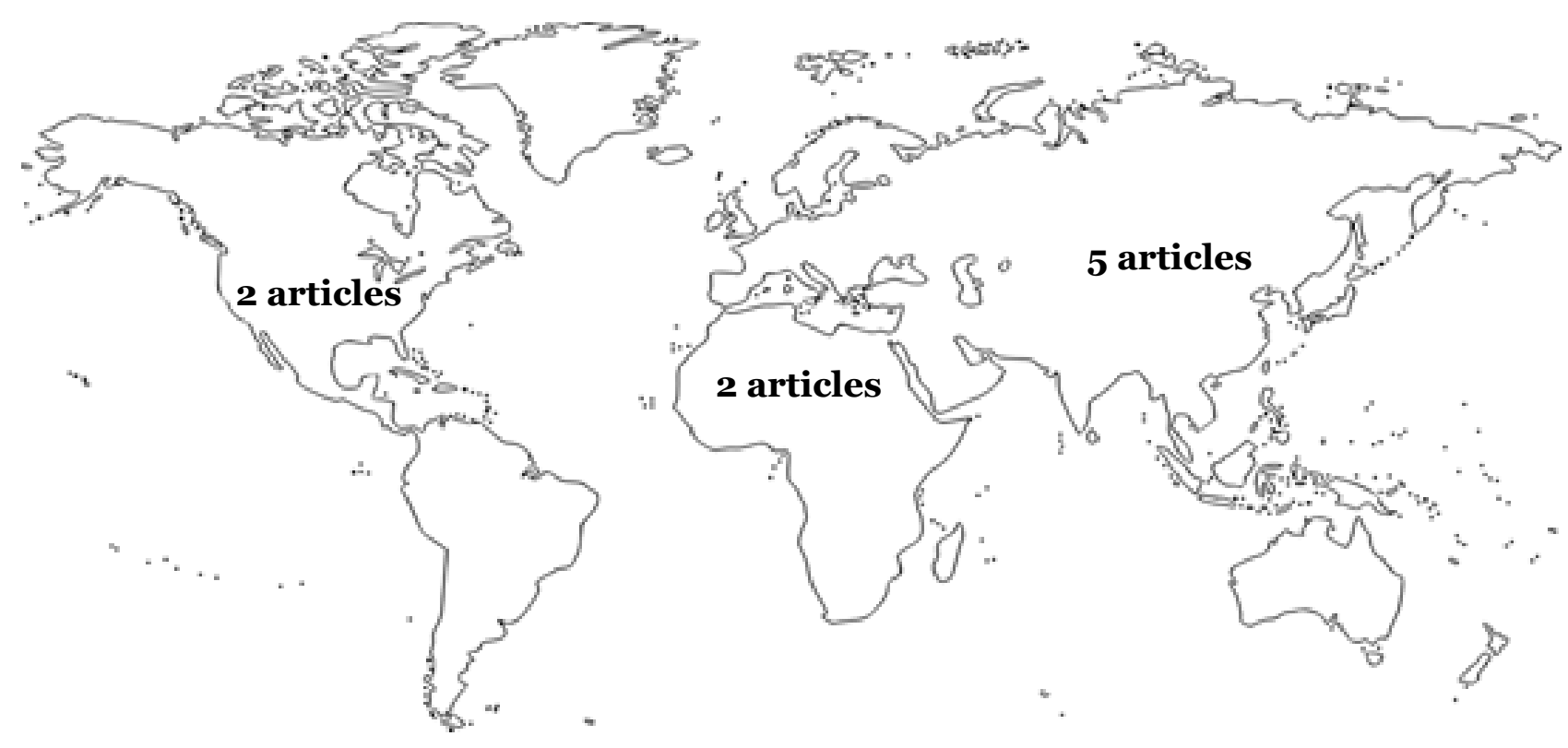
Figure 2. Map of the study area on the effect of blood
transfusion on hepatitis infection

There were 9 articles of the observational study with a cross-sectional study design as a source of a meta-analysis of the effect of blood transfusion on hepatitis C infection. An overview of the primary study conducted by the meta-analysis was in table 3 :

Table 1. The Summary Source of the effect of blood transfusion on hepatitis C infection

\begin{tabular}{|c|c|c|c|c|c|c|}
\hline $\begin{array}{l}\text { Author, } \\
\text { year }\end{array}$ & Title & Location & $\begin{array}{l}\text { Study } \\
\text { Design }\end{array}$ & $\begin{array}{l}\text { Sample } \\
\text { size }\end{array}$ & $\begin{array}{l}\text { Intervention (I) } \\
\text { and } \\
\text { Comparison (C) }\end{array}$ & Outcome \\
\hline $\begin{array}{l}\text { Aman et } \\
\text { al., } 2015\end{array}$ & $\begin{array}{l}\text { Prevalence and asso- } \\
\text { ciated factors of } \\
\text { hepatitis disease } \\
\text { patients on mainte- } \\
\text { nance hemodialysis } \\
\text { in three health cen- } \\
\text { ters in Aden, Yemen: } \\
\text { Cross-sectional study }\end{array}$ & Yamen & $\begin{array}{l}\text { Cross } \\
\text { sectional }\end{array}$ & 219 & $\begin{array}{l}\text { I: received a blood } \\
\text { transfusion. } \\
\text { C: Never received } \\
\text { a blood } \\
\text { transfusion }\end{array}$ & $\begin{array}{l}\text { Blood transfusions } \\
\text { increased the risk } \\
\text { of hepatitis B } \\
\text { infection in } \\
\text { hemodialysis } \\
\text { patients. }\end{array}$ \\
\hline $\begin{array}{l}\text { Alavian } \\
\text { et al., } \\
2003\end{array}$ & $\begin{array}{l}\text { Prevalence of Hepa- } \\
\text { titis C virus infection } \\
\text { and related risk fac- } \\
\text { tors among Iranian } \\
\text { Hemodialysis } \\
\text { Patients }\end{array}$ & Iran & $\begin{array}{l}\text { Cross } \\
\text { sectional }\end{array}$ & 838 & $\begin{array}{l}\text { I: Giving blood } \\
\text { transfusions } \geq 5 \\
\text { blood bags. } \\
\text { C: Giving blood } \\
\text { transfusions < } 5 \\
\text { blood bags. }\end{array}$ & $\begin{array}{l}\text { Giving blood trans- } \\
\text { fusions } \geq 5 \text { bags } \\
\text { increased the risk } \\
\text { of hepatitis B infec- } \\
\text { tion in hemodia- } \\
\text { lysis patients. }\end{array}$ \\
\hline $\begin{array}{l}\text { Nemati } \\
\text { et al., } \\
2009\end{array}$ & $\begin{array}{l}\text { Hepatitis C Virus } \\
\text { Infection Among } \\
\text { Patients on } \\
\text { Hemodialysis: A } \\
\text { Report from a Single } \\
\text { Centre in Iran }\end{array}$ & Iran & $\begin{array}{l}\text { Cross } \\
\text { sectional }\end{array}$ & 112 & $\begin{array}{l}\text { I: Giving blood } \\
\text { transfusions } \geq 5 \\
\text { blood bags. } \\
\text { C: Giving blood } \\
\text { transfusions < } 5 \\
\text { blood bags }\end{array}$ & $\begin{array}{l}\text { The number of } \\
\text { blood bags in blood } \\
\text { transfusions incre- } \\
\text { ased the risk of } \\
\text { hepatitis B infec- } \\
\text { tion in hemodia- } \\
\text { lysis patients. }\end{array}$ \\
\hline $\begin{array}{l}\text { Pereira, } \\
\text { et al., }\end{array}$ & $\begin{array}{l}\text { Prevalence and Risk } \\
\text { Factor Hepatitis C }\end{array}$ & Brazil & $\begin{array}{l}\text { Cross } \\
\text { sectional }\end{array}$ & 19,503 & $\begin{array}{l}\text { I: Giving blood } \\
\text { transfusions more }\end{array}$ & $\begin{array}{l}\text { Giving blood } \\
\text { transfusions for }\end{array}$ \\
\hline
\end{tabular}




\begin{tabular}{|c|c|c|c|c|c|c|}
\hline $\begin{array}{c}\text { Author, } \\
\text { year }\end{array}$ & Title & Location & $\begin{array}{c}\text { Study } \\
\text { Design }\end{array}$ & $\underset{\text { size }}{\text { Sample }}$ & $\begin{array}{c}\text { Intervention (I) } \\
\text { and } \\
\text { Comparison (C) }\end{array}$ & Outcome \\
\hline 2009 & $\begin{array}{l}\text { Virus Infection in } \\
\text { Brazil, 2005 Through } \\
\text { 2009: a Cross } \\
\text { Sectional Study }\end{array}$ & & & & $\begin{array}{l}\text { than } 12 \text { months. } \\
\text { C: Did not receive } \\
\text { blood } \\
\text { transfusions. }\end{array}$ & $\begin{array}{l}\text { more than } 12 \\
\text { months did not } \\
\text { have a significant } \\
\text { effect on hepatitis B } \\
\text { infection. }\end{array}$ \\
\hline $\begin{array}{l}\text { Yingying } \\
\text { et al., } \\
2013\end{array}$ & $\begin{array}{l}\text { Prevalence and Risk } \\
\text { Factors of Hepatitis } \\
\text { C and B Virus } \\
\text { Infection in } \\
\text { Hemodialysis } \\
\text { Patients : A } \\
\text { Multicenter Study in } \\
\text { Beijing China }\end{array}$ & China & $\begin{array}{l}\text { Cross } \\
\text { sectional }\end{array}$ & 2,120 & $\begin{array}{l}\text { I: Received a blood } \\
\text { transfusion before } \\
1998 . \\
\text { C: Received a } \\
\text { blood transfusion } \\
\text { after } 1998 \text {. }\end{array}$ & $\begin{array}{l}\text { Giving blood } \\
\text { transfusions before } \\
1998 \text { increased the } \\
\text { risk of hepatitis B } \\
\text { infection in } \\
\text { hemodialysis } \\
\text { patients. }\end{array}$ \\
\hline $\begin{array}{l}\text { Duong et } \\
\text { al., } 2015\end{array}$ & $\begin{array}{l}\text { Hepatitis B and C } \\
\text { virus infection } \\
\text { among patients with } \\
\text { end stage renal dise- } \\
\text { ase in a low- resour- } \\
\text { ced hemodialysis } \\
\text { center in Vietnam: A } \\
\text { Cross sectional study }\end{array}$ & Vietnam & $\begin{array}{l}\text { Cross } \\
\text { sectional }\end{array}$ & 113 & $\begin{array}{l}\text { I: Received more } \\
\text { than } 2 \text { blood } \\
\text { transfusions. } \\
\text { C: Received fewer } \\
\text { than } 2 \text { blood } \\
\text { transfusions. }\end{array}$ & $\begin{array}{l}\text { Giving blood } \\
\text { transfusions more } \\
\text { than } 2 \text { times } \\
\text { increased the } \\
\text { transmission of } \\
\text { hepatitis B } \\
\text { infection. }\end{array}$ \\
\hline $\begin{array}{l}\text { Carneiro, } \\
\text { et al., } \\
2001\end{array}$ & $\begin{array}{l}\text { Hepatitis C preva- } \\
\text { lence and risk factor } \\
\text { in hemodialysis } \\
\text { patients in Central } \\
\text { Brazil: a Survey by } \\
\text { Polymerase Chain } \\
\text { Reaction and } \\
\text { Serological Methods }\end{array}$ & Brazil & $\begin{array}{l}\text { Cross } \\
\text { sectional }\end{array}$ & 1,435 & $\begin{array}{l}\text { I: Giving } \\
\text { transfusion of } \geq 5 \\
\text { bags of blood. } \\
\text { C: No blood } \\
\text { transfusions or }<5 \\
\text { blood bags. }\end{array}$ & $\begin{array}{l}\text { Giving blood } \\
\text { transfusions } \geq 5 \\
\text { increased the } \\
\text { reactive outcome of } \\
\text { hepatitis B } \\
\text { infection on } \\
\text { serology. }\end{array}$ \\
\hline $\begin{array}{l}\text { Seek et } \\
\text { al., } 2014\end{array}$ & $\begin{array}{l}\text { Trends in Hepatitis C } \\
\text { infection among } \\
\text { hemodialysis pati- } \\
\text { ents in Senegal: } \\
\text { Result of a decade } \\
\text { prevention }\end{array}$ & Senegal & $\begin{array}{l}\text { Cross } \\
\text { sectional }\end{array}$ & 138 & $\begin{array}{l}\text { I: Giving blood } \\
\text { transfusions. } \\
\text { C: No blood } \\
\text { transfusions }\end{array}$ & $\begin{array}{l}\text { Blood transfusion } \\
\text { had a significant } \\
\text { effect on hepatitis B } \\
\text { infection in } \\
\text { hemodialysis } \\
\text { patients. }\end{array}$ \\
\hline $\begin{array}{l}\text { Kerollos } \\
\text { et al., } \\
2020\end{array}$ & $\begin{array}{l}\text { Prevalence and } \\
\text { Seroconversion of } \\
\text { Hepatitis C Among } \\
\text { Hemodialysis Pati- } \\
\text { ents in Assiut Gover- } \\
\text { norate, Egypt. }\end{array}$ & Egypt & $\begin{array}{l}\text { Cross } \\
\text { sectional }\end{array}$ & 428 & $\begin{array}{l}\text { I: Giving blood } \\
\text { transfusions. } \\
\text { C: No blood } \\
\text { transfusions. }\end{array}$ & $\begin{array}{l}\text { Blood transfusion } \\
\text { had a significant } \\
\text { effect on hepatitis B } \\
\text { infection in } \\
\text { hemodialysis } \\
\text { patients. }\end{array}$ \\
\hline
\end{tabular}

Based on table 1, the description of primary study conducted by meta-analysis had varied locations: the Asian Continent (5 articles), the African Continent (2 articles), and the Americas (2 articles). The sample size conducted by the study was above 100 patients. Q out of 9 articles did not have a significant effect of giving blood transfusions on the incidence of hepatitis $\mathrm{C}$ infection.

\section{Forest Plot}

The interpretation of the results of the metaanalysis of primary study of the effect of blood transfusions on hepatitis C infection in hemodialysis patients is presented in the forest plot. 
Astuti et al./ Effects of Blood Transfusion on the Risk of Hepatitis C Infection

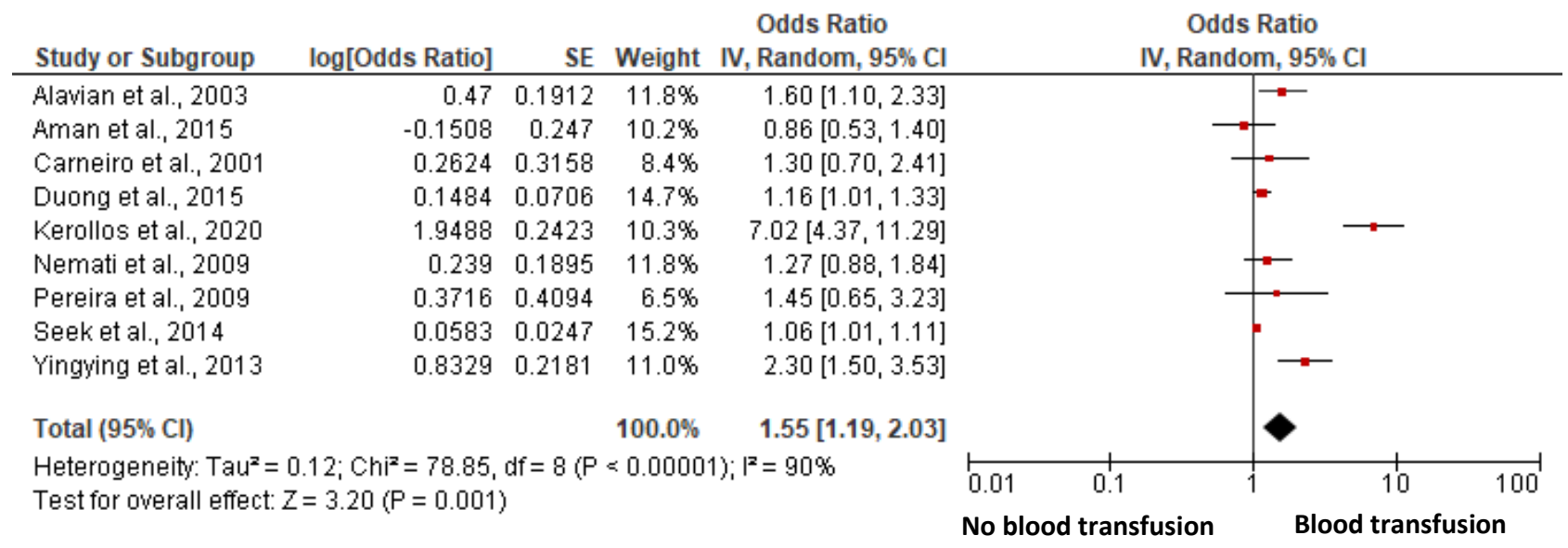

\section{Figure 5. forest plot of the blood transfusion on the incidence of hepatitis $\mathrm{C}$ infection}

Based on the analysis results in Figure 5, 9 articles explained that blood transfusion was one of the risk factors affecting the incidence of hepatitis C infection in hemodialysis patients. Meanwhile, there was high heterogeneity among primary studies $\left(\mathrm{I}^{2}=90 \%\right.$; $\mathrm{p}<0.00001)$. Therefore, it used Random Effect Model. In the data analysis in the forest plot, giving blood transfusions increased the risk of the incidence of hepatitis $\mathrm{C}$ infection in hemodialysis patients 1.55 times higher than those who did not. The result was statistically significant $(\mathrm{aOR}=1.55 ; 95 \% \mathrm{CI}=$ 1.19-2.03; $\mathrm{p}=0.001$ ).

\section{Funnel Plot}

Funnel plot was a plot that showed the estimated effect size of each study on its estimate of accuracy. It was usually the standard error.

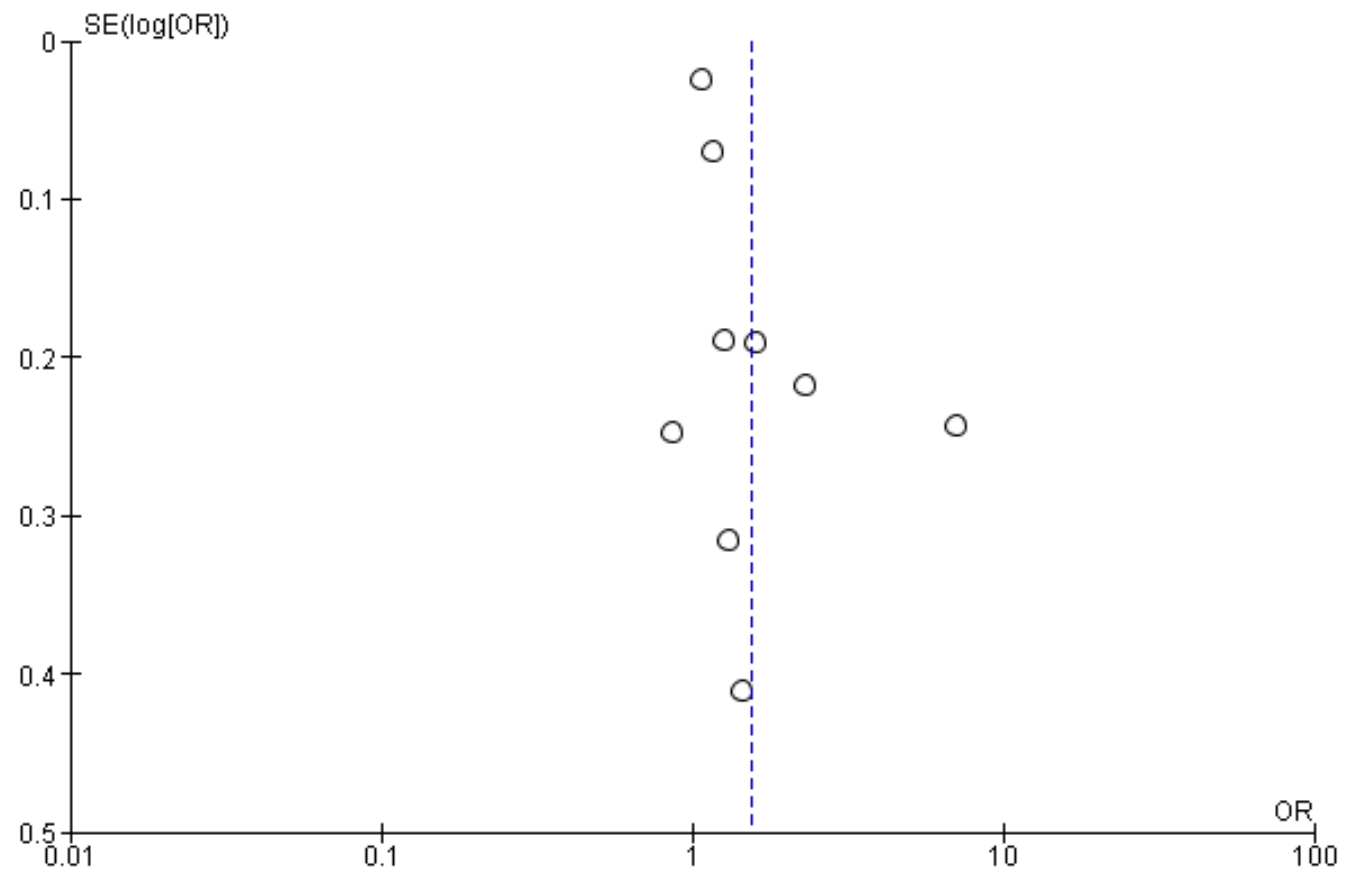

Figure 6. The funnel plot of the effect of blood transfusions on hepatitis $\mathrm{C}$ infection 
Based on Figure 6, there was no publication bias characterized by a symmetrical primary study in the funnel plot.

\section{DISCUSSION}

This systematic review and meta-analysis study was about the effect of blood transfusion on hepatitis $\mathrm{C}$ infection in hemodialysis patients. A study that discussed the data on hepatitis $\mathrm{C}$ infection was considered important because it was rarely conducted. The number of the relevant studies published and accessible was still small and also had data access problems (data duplication) (Murti, 2018). Most of the statistical results reported were in the total percentage or a crude odd Ratio (cOR), where the study did not control for confounding factors.

Confounding factors that affected the relationship or effect of exposure to the occurrence of disease estimated by the study were not the same as the relationship or effect that occurred in the target population, which means that the study results were invalid (Murti, 2018). This systematic and meta-analysis study used a study that controlled for confounding factors. It showed from the study inclusion requirements such as multivariate analysis. The statistical result reported was in the adjusted odd ratio (aOR).

The estimation of the association between blood transfusions and the incidence of hepatitis $\mathrm{C}$ infection was processed using the RevMan 5.3 application with the generic inverse-variance method. This method aimed to analyze data in the form of rate, time-toevent, hazard ratio, ordinal scale, adjusted estimate, difference of mean, or ratio of mean.

The results of the systematic and metaanalysis study were presented in the form of a forest plot and a funnel plot. The forest plot in the meta-analysis results showed visually the amount of variation (heterogeneity) (Akobeng, 2005 in Murti, 2018). The funnel plot showed the relationship between the effect size of the study and the sample size of the various studies studied. It could be measured in several different ways (Murti, 2018). The funnel plot showed the effect size on the sample size. The funnel plot aimed to see publication bias from the results of metaanalysis studies from combined primary studies. If the dots formed an inverted funnel, with a wide base that narrowed towards the top of the plot, and the dots between right and left were balanced, it means that there was no publication bias. However, if the dots formed an asymmetrical shape between the right and left sides, the publication bias could be suspected (Ahn and Kang, 2018).

Based on the results of the forest plot, blood transfusions could increase the incidence of hepatitis $\mathrm{C}$ infection 1.55 times compared to those who did not receive transfusions, and the result was statistically significant $(\mathrm{p}=0.001)$. Blood transfusion was associated with the incidence of hepatitis $\mathrm{C}$. Hemodialysis patients were in a group that was susceptible to hepatitis $\mathrm{C}$ infection if there was a history of repeated blood transfusions (Amiri et al., 2005).

The prevalence of hepatitis $\mathrm{C}$ infection was greater in hemodialysis patients than in other patients. Immunosuppressive conditions in hemodialysis patients caused conditions that were susceptible to infection. In a study conducted by (Caragea et al., 2018), several cases increased when they were in the hemodialysis center. The patients were infected during the transfusion. It occurred due to improper disinfecting and aseptic intervention, inappropriate screening for blood components, and the inability of the health personnel to provide transfusion services.

Hemodialysis patients who carried out blood transfusions would increase the risk of exposure and contamination with hepatitis C. The condition of nosocomial infections in the transfusion process often makes hemodialy- 
sis patients susceptible to infection. Nosocomial infections could come from the health personnel or the equipment used during the transfusion process. Hemodialysis patients were expected to be screened to check whether they were infected with hepatitis $\mathrm{C}$ or not. In some cases, hemodialysis patients were difficult to diagnose whether they were infected with hepatitis C or not because some patients had asymptomatic (Contanscio et al., 2018).

The small number of articles included in the meta-analysis that met the inclusion criteria was a limitation of this study. There was a language bias because this study used English articles only, thus ignoring nonEnglish articles. There was a search bias because this study used 6 databases only (Research Gate, PubMed, SpringerLink, Elsevier, Science Direct, and Google Scholar), thus ignoring other search sources.

\section{AUTHOR CONTRIBUTION}

Yuli Astuti was the main researcher.As the main researcher, Yuli Astuti had a role in proposing the ideas of the study, coordinating at all stages of the study, and completing the paper. Yulia Lanti Retno Dewi had a role in developing ideas, study designs, and study hypotheses. Bhisma Murti formulated the study design and did data analysis.

\section{CONFLICT OF INTEREST}

The abstract of this study was presented for an oral presentation at the 7 th International Conference of Public Health.

\section{FUNDING AND SPONSORSHIP}

The source of funds in this study used personal funds from the main researcher.

\section{ACKNOWLEDGEMENT}

The author would like to express his gratitude to the Jenderal Achmad Yani Yogyakarta University to support this researches.

\section{REFERENCE}

Ahn E, Kang H (2018). Introduction to Systematic Review and Meta-Analysis: A Health Care Perspective. Korean J Anesthesiol, 71(2), 1-38.

Amiri Z, Shakib A, Toorchi M (2005). Seroprevalence of hepatitis $\mathrm{C}$ and risk factors in haemodialysis patients in Guilan, Islamic Republic of Iran. EMHJ, 11(3), 372-376.

Caragea D, Mihailovici AR, Streba CT, Schenker M, Ungureanu B, Caragea IN, Popa R, Obleaga C, Vere CC (2018). Hepatitis $\mathrm{C}$ infection in Hemodialysis Patients. Curr Health Sci J, 44(2): 107-112.

Centers for Disease Control (2012). Hepatitis B-2012. Yellow Book. Retrieved from wwwnc.cdc.gov/travel/yellowbook/2014/chapter-3-infectious-diseases-related-to-travel/hepatitis-b.

Contantio NS, Feraz M, Martin CT, Kraychete AC, Bitencourt PL, Nascimento MM (2018). Hepatitis C in Hemodialysis Unit : Diagnosis and Theraupetic Approach. J Braz Nefrol, 11(4):539-549.

Engle R, Bukh J, Alter H, Emerson S, Trenbeath, Nguyen, Purcell RH. (2014). Transfusion-associated hepatitis before the screening of blood for hepatitis risk factors. Transfusion J, 54(11), 28332841.

Han R, Zhou J, Francois C, Thoumi M (2019). Prevalence of hepatitis C infection among the general population and high-risk groups in the EU/EEA: a systematic review update. BMC Infect Dis, 19(1), 1-14.

Lopez L, Patricia L, Arago A, Rodiguez I, Jorge, LIma E, Insagaray J, Bentancor $\mathrm{N}$ (2005). Risk factor for hepatitis B and $\mathrm{C}$ in Multi-tranfused patient in Urugay. Journal of Clin Virol, 34 (2), S69-74.

La TG, Saulle R (2016). Risk factors from hepatitis $\mathrm{B}$ infection among blood 
Astuti et al./ Effects of Blood Transfusion on the Risk of Hepatitis C Infection

donors: A systematic review. Asian Pac J Trop Biomed, 6(4), 344-349.

Morozov VA, Lagaye S (2018). Hepatitis C virus: Morphogenesis, infection and therapy. World J Hepatol, 27;10(2):186-212

Murti B (2016). Prinsip dan Metode Riset Epidemiologi. Colomadu, Karanganyar. Bintang Fajar Offset.

Oliveira AB, Piementa C, Rojas M, Chagaz M, Crespo M, Cresente B, Lemos R (2010). Likely transmission of hepatitis $\mathrm{C}$ virus through sharing of cutting and perforating instruments in blood donors in the State of Pará, Northern Brazil. SciELO, 26(4):837-844.

Vadakedath S, Kandi V. 2017. Dyalisis: A Review of the Mechanisme Underlying Complications in the Management of Chronic Renal Failure. Cureus 9(8): 1603
World Health Organization (2012). Guidlines on Assess Donor Suitability for Blood Donation.

WHO (2020a) . What is Hepatitis?. Retrieved from https://www.who.int/newsroom/q-a-detail/what-is-hepatitis. on June 10, 2020.

WHO (2020b). Clinical Transfusion Practice Guidelines for Medical Interns. Retrieved from https:www.who.int/bloodsafety/transfusion_services/ClinicalTransfusionPracticeGuidelinesforMedicalInternsBangladesh.pdf

Yelima JD, Ufelle, Milgwe, Oyeleke, Denue, Chickwendu (2019). Complications of blood transfusion and management: Definitions And History Of Blood group systems. Eajournals Vol 7: (3): 25-34. 